\title{
Irrigation as a method of preventing detrimental late tillering of barley
}

\author{
Simo Kivisaari and Paavo Elonen ${ }^{1}$ ) \\ University of Helsinki, Department of Agricultural Chemistry, 00710 Helsinki 71
}

\begin{abstract}
The present study was carried out in summer 1970, when a rainy July following upon a dry June caused abundant detrimental late tillering among spring cereals in large parts of South Finland, and in part also in Central and North Finland.

In four irrigation experiments, established in the clay area of South Finland, the irrigation performed in the middle of June $(2 \times 30 \mathrm{~mm})$ increased the yield of tworowed barley by $1750 \mathrm{~kg} / \mathrm{ha}$ on an average or by $71 \%$ (variation range $49-104 \%$ ). In addition irrigation improved the quality of barley significantly by preventing detrimental late tillering. The irrigated evenly ripened barley was at harvesting time on an average 12.3 per cent units drier, with a hectolitre weight that was $3.6 \mathrm{~kg}$ higher when compared to the non-irrigated green grained barley.

Analyses of the sheaves collected from the fields indicated that irrigated barley when compared to non-irrigated barley contained: a) equally many individuals per square meter, b) $14 \%$ less ears per individual, c) $83 \%$ more grains per ear, d) $9 \%$ heavier grains; in fact the total result was a $70 \%$ higher grain yield.

Causes of late tillering and the significance of irrigation in preventing this detrimental phenomenon are discussed. It is further established that in years when no late tillering occurs, irrigation affects the grain yield components in ways that differ from those established in the present study.
\end{abstract}

\section{Introduction}

In the short Finnish summer plants develop fast. Spring cereals are sown in South Finland usually in mid-May, the earing time is at the beginning of July and the yield can be harvested at the end August or early September. June, the month with the largest amount of radiation energy for plants to use, is usually too dry so that the vegetative growth is poor. On the other hand, July may be very rainy. When a dry June is followed by a rainy July, the sparse spring cereal population produces detrimental late tillering. The sprouts that have developed late do not have sufficient time to mature and to increase

1) Present address: Agricultural Research Centre, Department of Soil Science, 01300 Vantaa 30. 
the yield. In fact they tend to impede the harvesting, grain drying and winnowing, thereby making the yield quality poorer.

In 1970 exceptionally abundant late tillering occurred in entire South Finland and also in some areas in Central and North Finland. In soils with favourable moisture conditions no detrimental late tillering occurred and the plant stands developed vigorously already in June. The fields irrigated in June also matured evenly.

The present study examines the influence of irrigation on the tillering and yield formation of barley in the growing conditions of the year 1970.

\section{Experimental procedures}

In the year 1970 the Department of Agricultural Chemistry and the Finnish Research Institute of Engineering in Agriculture and Forestry arranged irrigation experiments of spring cereals on ten farms in South Finland. Four of the farms growing two-rowed barley were chosen for this study. The varieties were Ingrid and Karri. The farms were as follows:

\begin{tabular}{llcc} 
Farm & Parish & \multicolumn{2}{c}{ Geographical location } \\
& & N & E \\
1 Ojala & Haùsjärvi & $60^{\circ} 50^{\prime}$ & $25^{\circ} 06^{\prime}$ \\
2 Kuutti & Tyrvää & $61^{\circ} 13^{\prime}$ & $23^{\circ} 08^{\prime}$ \\
3 Tiuttu & Huittinen & $61^{\circ} 10^{\prime}$ & $22^{\circ} 46^{\prime}$ \\
4 Topi-Hulmi & Loimaa & $60^{\circ} 52^{\prime}$ & $23^{\circ} 00^{\prime}$
\end{tabular}

The soil type of the fields was silty or loamy clay. The average amount of nitrogen given in the mixed fertilizers was $90-110 \mathrm{~kg} / \mathrm{ha}$. The fertilizers were placed at the same time as the seeds with a combined sowing machine. The sowing time was 13. -21. 5.

The fields were irrigated twice with ordinary rotary sprinklers at one or two week intervals during the period 11.-24.6. The amount of water given at each time was about $30 \mathrm{~mm}$ and the water was taken from a river or a lake. In each experimental field there were three irrigated and three non-irrigated plots, respectively.

The grain yields were harvested with a combine 28. 8.-11.9. The size of the harvested experimental plot was $2 \times 30 \mathrm{~m}^{2}$. The grains were dryed, winnowed and analysed.

In connection with the harvesting individual plants were collected into two sheaves from each experimental plot the area concerned being $0.50 \mathrm{~m}^{2}$ in size. The plants were pulled up without hurting the shoots. A total of 48 sheaves were collected. They were analysed as follows:

1. Number of individual plants $/ \mathrm{m}^{2}$

2. Sprouting intensity of individual plants (number of ears/plant)

3. Number of grains in ears of different stages

4. Weight of grains in ears of different stages 
Table 1. Precipitation and soil moisture. (Precipitation: as sums of five day periods. Soil moisture: $\%$ of plant available water capacity at depth of $17.5 \mathrm{~cm}$, mean values of five day periods.)

\begin{tabular}{|c|c|c|c|c|c|c|c|c|c|}
\hline \multirow[t]{2}{*}{ Period } & & \multicolumn{4}{|c|}{$\begin{array}{l}\text { Precipitation mm } \\
\text { Farm No. }\end{array}$} & \multicolumn{4}{|c|}{$\begin{array}{c}\text { Soil moisture \% } \\
\text { Farm No. }\end{array}$} \\
\hline & & 1 & 2 & 3 & 4 & 1 & 2 & 3 & 4 \\
\hline \multirow[t]{6}{*}{ June } & $1-5 \quad \ldots$ & 3 & 0 & 0 & 5 & 26 & 68 & 37 & 26 \\
\hline & 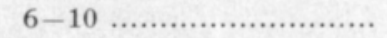 & 0 & 0 & 15 & 4 & 21 & 52 & 34 & 24 \\
\hline & 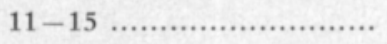 & 7 & 0 & 0 & 4 & 15 & 36 & 24 & 21 \\
\hline & 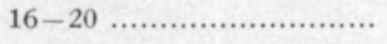 & 0 & 0 & 0 & 0 & 4 & 18 & 14 & 20 \\
\hline & 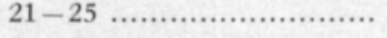 & 0 & 0 & 0 & 0 & 1 & 3 & 4 & 13 \\
\hline & $26-30 \ldots \ldots \cdots \cdots \cdots \cdots \cdots \cdots \cdots \cdots \cdots \cdots \cdots \cdots \cdots \cdots$ & 1 & 10 & 14 & 2 & 0 & 0 & 0 & 4 \\
\hline \multirow[t]{6}{*}{ July } & 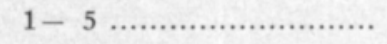 & 10 & 22 & 7 & 22 & 7 & 14 & 0 & 3 \\
\hline & 6-10 …...................... & 3 & 4 & 11 & 12 & 36 & 47 & 0 & 9 \\
\hline & 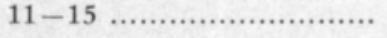 & 12 & 39 & 16 & 44 & 67 & 80 & 0 & 14 \\
\hline & $16-20 \ldots \ldots \ldots \ldots \ldots \ldots \ldots \ldots \ldots \ldots \ldots \ldots \ldots \ldots$ & 25 & 26 & 11 & 4 & 85 & 93 & 0 & 15 \\
\hline & $21-25 \ldots \ldots \ldots \ldots \ldots \ldots \ldots \ldots$ & 22 & 18 & 11 & 7 & 66 & 76 & 0 & 12 \\
\hline & $26-31 \ldots \ldots \ldots \ldots \ldots \ldots \ldots \ldots$ & 13 & 13 & 13 & 18 & 45 & 45 & 0 & 8 \\
\hline
\end{tabular}

As can be seen from Table 1 June was on each farm very dry. The amounts of rain varied between 10 and $29 \mathrm{~mm}$, the mean being only $16 \mathrm{~mm}$. July on the other hand was exceptionally rainy, $69-132 \mathrm{~mm}$, with an average value of $98 \mathrm{~mm}$. Precipitation in July divided fairly evenly in that no farm had a rainless five-day period.

The soil moisture conditions in the lower part of the plough layer, at a depth of $17.5 \mathrm{~cm}$ were observed with the method of Bouyoucos' gypsum blocks. The plough layer was too dry on all the experimental farms during the whole of June, and especially at the end of June, when the water available to the plants was almost finished. The rains in July moistened the whole plough layer on the farms 1 and 2 , on the farms 3 and 4 , however, only the upper part of the layer was moistened. On farm No. 3, which had the smallest as well as the most even amount of precipitation in July, the lower part of the plough layer remained for the whole month at wilting point.

Abundant late tillering occurred on all farms in the non-irrigated plots due to the rains in July, in the irrigated plots the barley, however, matured evenly.

\section{Combine-harvested grain yields}

The combine-harvested grain yields of the large experimental plots $(2 \times$ $30 \mathrm{~m}^{2}$ ) are presented in Table 2. Irrigation increased the barley yields significantly on all farms. The increases in yields varied from $1420 \mathrm{~kg} / \mathrm{ha}$ to $2060 \mathrm{~kg} / \mathrm{ha}$, or from 49 to 104 per cent, the mean value being $+1750 \mathrm{~kg} / \mathrm{ha}$ or +71 per cent. 
Table 2. Grain yields (moisture $15 \%$ ).

\begin{tabular}{|c|c|c|c|c|c|c|c|}
\hline \multirow[t]{2}{*}{ Farm } & \multirow[t]{2}{*}{ Irrigation } & \multicolumn{2}{|c|}{ Grain yield } & \multirow{2}{*}{$\begin{array}{c}\text { Moisture } \\
\text { at } \\
\text { harvest } \\
\%\end{array}$} & \multirow{2}{*}{$\begin{array}{c}\text { Green } \\
\text { grains } \\
\%\end{array}$} & \multirow{2}{*}{$\begin{array}{c}\text { Hectolitre } \\
\text { weight } \\
\text { kg }\end{array}$} & \multirow{2}{*}{$\begin{array}{c}1000- \\
\text { grain } \\
\text { weight } \\
\text { g }\end{array}$} \\
\hline & & $\mathrm{kg} / \mathrm{ha}$ & $\begin{array}{c}\text { relative } \\
\text { value }\end{array}$ & & & & \\
\hline \multirow[t]{3}{*}{1} & Unirrigated ........ & 2660 & 100 & 34.2 & 8.4 & 63.7 & 41.8 \\
\hline & Irrigated ............ & 4720 & 177 & 19.2 & 0.2 & 67.2 & 46.2 \\
\hline & Effect $\ldots \ldots \ldots \ldots \ldots$ & $+2060^{*}$ & $+77^{*}$ & $-15.0^{*}$ & $-8.2^{*}$ & +3.5 & +4.4 \\
\hline \multirow[t]{3}{*}{2} & Unirrigated ........ & 2890 & 100 & 43.6 & 4.1 & 59.2 & 38.0 \\
\hline & Irrigated ........... & 4310 & 149 & 32.0 & 0.8 & 63.4 & 40.2 \\
\hline & Effect ................ & $+1420^{* *}$ & $+49^{* *}$ & $-11.6^{*}$ & -3.3 & $+4.2 * * *$ & $+2.2^{*}$ \\
\hline \multirow[t]{3}{*}{3} & Unirrigated ....... & 2680 & 100 & 33.0 & 3.0 & 62.9 & 41.2 \\
\hline & Irrigated ............ & 4520 & 169 & 22.6 & 0.7 & 66.1 & 50.8 \\
\hline & Effect ................. & $+1840^{* *}$ & $+69 * *$ & $-10.4 * * *$ & $-2.3^{*}$ & $+3.2^{*}$ & $+9.6^{* * *}$ \\
\hline \multirow[t]{3}{*}{4} & Unirrigated ........ & 1630 & 100 & 43.9 & 13.9 & 61.6 & 40.6 \\
\hline & Irrigated ............ & 3320 & 204 & 32.1 & 5.9 & 65.1 & 42.1 \\
\hline & Effect............ & $+1690^{*}$ & $+104^{*}$ & $-11.8^{*}$ & $-8.0^{*}$ & $+3.5^{* *}$ & $+1.5^{*}$ \\
\hline \multirow[t]{3}{*}{ Mean } & Unirrigated ....... & 2470 & 100 & 38.7 & 7.4 & 61.9 & 40.4 \\
\hline & Irrigated ............ & 4220 & 171 & 26.4 & 1.9 & 65.5 & 44.8 \\
\hline & Effect $\ldots \ldots \ldots \ldots \ldots$ & $+1750^{* *}$ & $+71^{* * *}$ & $-12.3^{* * *}$ & $-5.5^{* * *}$ & $+3.6^{* * *}$ & $+4.4^{* *}$ \\
\hline & $\begin{array}{ll}* & \text { significant d } \\
* * & * *\end{array}$ & $\begin{array}{ll}\text { fference, } & \mathrm{P} \\
& \mathrm{P} \\
& \mathrm{P}\end{array}$ & $\begin{array}{l}0.05 \\
0.01 \\
0.001\end{array}$ & & & & \\
\hline
\end{tabular}

The quality of the harvested barley was likewise far better on the irrigated plots. The grain moisture was on an average $12.3 \%$-units dryer on the irrigated plots as compared to the non-irrigated ones. In addition, the irrigated barley matured evenly, while the non-irrigated barley contained overripe as well as green grains. Despite drying and winnowing the non-irrigated barley still contained $7.4 \%$ green grains. The corresponding figure in irrigated barley was $1.9 \%$.

Owing to the more even ripening, the hectolitre and the 1000 grain weights were also bigger in the irrigated than in the non-irrigated grains, the former being $3.6 \mathrm{~kg}$ higher and the latter $4.4 \mathrm{~g}$ or $11 \%$ higher.

Analyses of sheaves

Density of stand

The mean values of the densities of stands are presented in Table 3 . The average number of individual plants was about $400 / \mathrm{m}^{2}$. On farms 2 and 3 the density was even higher while on farm No. 4 it was lower. This was due 
Table 3. Plant density (number of barley individuals per $\mathrm{m}^{2}$ ).

\begin{tabular}{lllll}
\hline Experimental farm & Unirrigated & Irrigated & Effect \\
\hline No. $1 \ldots \ldots \ldots \ldots \ldots$ & 506 & 476 & -30 \\
No. $2 \ldots \ldots \ldots \ldots \ldots$ & 376 & 380 & +4 \\
No. 3 & $\ldots \ldots \ldots \ldots$. & 458 & 478 & +20 \\
No. $4 \ldots \ldots \ldots \ldots \ldots$ & 252 & 240 & -12 \\
Mean $\ldots \ldots \ldots \ldots \ldots$ & 398 & 394 & -4 \\
\hline
\end{tabular}

to heavy rain immediately after the sowing which had destroyed the soil structure badly so that the shooting was poor.

The effect of irrigation on the number of individual plants per square meter was not significant on any of the experimental farms. This is doubtless due to the time of irrigation which was about one month after the sowing, and thus could not influence the sprouting. On the other hand, irrigation had no effect on the wilting of the weakest plants either, which may occur in a very dry summer. Owing to the rains in July it seems probable that all the sprouted barley plants remained alive until harvesting time also in the non-irrigated plots.

\section{Tillering}

The tillering of barley was more abundant without irrigation than when irrigation had been performed (Table 4). On an average, one barley plant individual had 2.44 ears without irrigation and 2.11 ears or $14 \%$ less when irrigated. Likewise, the number of ears per square meter was on an average $14 \%$ smaller in the irrigated plots as compared to the non-irrigated ones. The effect of irrigation on the tillering was similar on all four experimental farms, the order of magnitude being also about the same: irrigation diminished the number of ears per plant individual by $11-18 \%$ and per area unit by $8-17 \%$.

If only the ripened ears are considered, the above differences are smaller. This is due to the fact that the percentage of green ears on irrigated plots was only $2 \%$ while without irrigation the average was $8 \%$. Green ears occurred only on three farms while on farm No. 2 they were almost absent. This was no doubt due to the late harvesting time and the preceding rains which affected the colour of the ears to such an extent that the unripe ears could not be separated on the basis of the pale green colour. Judging by the results shown in Table 2 it may be concluded, however, that the non-irrigated barley on farm No. 2 likewise contained unripe ears.

Detailed results of the tillering of the barley are presented in Table 5. Irrigated stands contained more one-eared plants than the non-irrigated stands, the number of 2- and 3-ear plants was almost equal but the number of plants having four or more ears was bigger in the non-irrigated than in the irrigated plots. On farms 1 and 4, where the densities of the stands were lowest (Table 3) tillering was most abundant and considerable numbers of plants even had more than six ears. 
Table 4. Tillering of barley (mean values).

\begin{tabular}{|c|c|c|c|c|c|c|c|}
\hline \multirow[t]{2}{*}{ Farm } & \multirow[t]{2}{*}{ Irrigation } & \multicolumn{3}{|c|}{ No. of ears per $\mathrm{m}^{2}$} & \multicolumn{3}{|c|}{ No. of ears per individual } \\
\hline & & Ripened & Green & Total & Ripened & Green & Total \\
\hline \multirow[t]{3}{*}{1} & Unirrigated .. & 904 & 126 & 1030 & 1.80 & 0.24 & 2.04 \\
\hline & Irrigated ........ & 866 & 0 & 866 & 1.82 & 0 & 1.82 \\
\hline & Effect ........... & -38 & $-126 * *$ & $-164^{*}$ & +0.02 & $-0.24 * *$ & $-0.22 *$ \\
\hline \multirow[t]{3}{*}{2} & Unirrigated ... & 1126 & 3 & 1129 & 2.99 & 0.01 & 3.00 \\
\hline & Irrigated ........ & 936 & 0 & 936 & 2.46 & 0 & 2.46 \\
\hline & Effect ........... & -190 & -3 & -193 & $-0.53 * *$ & -0.01 & $-0.54^{* *}$ \\
\hline \multirow[t]{3}{*}{3} & Unirrigated ... & 784 & 146 & 930 & 1.71 & 0.32 & 2.03 \\
\hline & Irrigated ........ & 817 & 36 & 853 & 1.71 & 0.07 & 1.78 \\
\hline & Effect ......... & +33 & $-110^{* * *}$ & -77 & 0 & $-0.25 * *$ & $-0.25^{*}$ \\
\hline \multirow[t]{3}{*}{4} & Unirrigated ... & 739 & 54 & 793 & 2.93 & 0.22 & 3.15 \\
\hline & Irrigated ........ & 658 & 16 & 674 & 2.74 & 0.07 & 2.81 \\
\hline & Effect .......... & -81 & -38 & -119 & -0.19 & -0.15 & -0.34 \\
\hline \multirow[t]{3}{*}{ Mean } & Unirrigated .. & 888 & 82 & 970 & 2.23 & 0.21 & 2.44 \\
\hline & Irrigated ........ & 819 & 13 & 832 & 2.08 & 0.03 & 2.11 \\
\hline & Effect ........... & -69 & $-69 * * *$ & $-138 * *$ & -0.15 & $-0.18 * * *$ & $-0.33 * * *$ \\
\hline
\end{tabular}

Table 5. Tillering of barley individuals (more detailed analyses).

\begin{tabular}{|c|c|c|c|c|c|c|c|c|}
\hline \multirow[t]{2}{*}{ Farm } & \multirow[t]{2}{*}{ Irrigation } & \multicolumn{7}{|c|}{ No. of barley individuals per $\mathrm{m}^{2}$ having } \\
\hline & & 1 ear & 2 ears & 3 ears & 4 ears & 5 ears & 6 ears & $>6$ ears \\
\hline \multirow[t]{3}{*}{1} & Unirrigated ..... & 216 & 152 & 78 & 38 & 14 & 6 & 2 \\
\hline & Irrigated ........... & 204 & 170 & 90 & 12 & 0 & 0 & 0 \\
\hline & Effect........... & -12 & +18 & +12 & $-26 * *$ & $-14^{* *}$ & $-6^{*}$ & -2 \\
\hline \multirow[t]{3}{*}{2} & Unirrigated ..... & 114 & 64 & 70 & 48 & 28 & 20 & 32 \\
\hline & Irrigated ........... & 146 & 76 & 74 & 42 & 18 & 12 & 12 \\
\hline & Effect . ............. & +32 & +12 & +4 & -6 & -10 & $-8^{*}$ & $-20 * * *$ \\
\hline \multirow[t]{3}{*}{3} & Unirrigated ..... & 146 & 180 & 104 & 25 & 2 & 1 & 0 \\
\hline & Irrigated ........... & 220 & 165 & 70 & 20 & 2 & 0 & 0 \\
\hline & Effect .............. & $+74^{* *}$ & -14 & $-34 * *$ & -5 & 0 & -1 & 0 \\
\hline \multirow[t]{3}{*}{. 4} & Unirrigated ..... & 52 & 51 & 57 & 41 & 26 & 11 & 14 \\
\hline & Irrigated ........... & 58 & 53 & 57 & 40 & 19 & 8 & 5 \\
\hline & Effect...$\ldots \ldots \ldots \ldots$ & +6 & +2 & 0 & -1 & -7 & -3 & -9 \\
\hline \multirow[t]{3}{*}{ Mean } & Unirrigated ..... & 132 & 112 & 77 & 38 & 18 & 9 & 12 \\
\hline & Irrigated ........... & 157 & 116 & 73 & 29 & 10 & 5 & 4 \\
\hline & Effect ............. & $+25^{*}$ & +4 & -4 & $-9^{*}$ & $-8 * *$ & $-4^{*}$ & $-8^{* * *}$ \\
\hline
\end{tabular}


Table 6. Number of green ears per $\mathrm{m}^{2}$.

\begin{tabular}{|c|c|c|c|c|c|c|c|c|}
\hline \multirow[t]{2}{*}{ Farm } & \multirow[t]{2}{*}{ Irrigation } & \multicolumn{7}{|c|}{ Green ears in barley individuals containing } \\
\hline & & 1 ear & 2 ears & 3 ears & 4 ears & 5 ears & 6 ears & $>6$ ears \\
\hline \multirow[t]{3}{*}{1} & Unirrigated ...... & 24 & 30 & 28 & 18 & 14 & 8 & 4 \\
\hline & Irrigated ............ & 0 & 0 & 0 & 0 & 0 & 0 & 0 \\
\hline & Effect ......................... & $-24^{*}$ & $-30^{*}$ & $-28 * *$ & $-18^{* *}$ & $-14^{*}$ & $-8^{*}$ & -4 \\
\hline \multirow[t]{3}{*}{2} & Unirrigated ...... & 3 & 0 & 0 & 0 & 0 & 0 & 0 \\
\hline & Irrigated ........... & 0 & 0 & 0 & 0 & 0 & 0 & 0 \\
\hline & Effect .............. & -3 & 0 & 0 & 0 & 0 & 0 & 0 \\
\hline \multirow[t]{3}{*}{3} & Unirrigated ...... & 16 & 54 & 50 & 20 & 6 & 0 & 0 \\
\hline & Irrigated ........... & 2 & 14 & 10 & 8 & 2 & 0 & 0 \\
\hline & Effect ............... & $-14^{*}$ & $-40 * * *$ & $-40^{* *}$ & $-12^{*}$ & -4 & 0 & 0 \\
\hline \multirow[t]{3}{*}{4} & Unirrigated ...... & 6 & 10 & 12 & 12 & 8 & 2 & 4 \\
\hline & Irrigated ........... & 4 & 0 & 2 & 2 & 4 & 2 & 2 \\
\hline & Efect ............... & -2 & -10 & -10 & -10 & -4 & 0 & -2 \\
\hline \multirow[t]{3}{*}{ Mean } & Unirrigated ..... & 12 & 23 & 22 & 13 & 7 & 3 & 2 \\
\hline & Irrigated .......... & 2 & 4 & 3 & 3 & 1 & 0 & 0 \\
\hline & Effect .............. & $-10^{\star \star \star *}$ & $-19^{\star \star \star}$ & $-19 * * *$ & $-10^{\star \star}$ & $-6^{\star \star}$ & -3 & -2 \\
\hline
\end{tabular}

Table 6 presents the distribution of green ears between different groups of individuals. A comparison of Tables 5 and $\mathbf{6}$ shows that the proportions of green ears are about equal in the different groups: without irrigation the average proportion of green ears was about $8 \%$ of the total number of ears irrespective of whether one-ear individuals or five-ear individuals were under consideration. It also seems likely that irrigation diminished the proportion of green ears in all individual groups at the same approximate rate.

In Table 6 special attention should be paid to the proportion of green ears in the one-ear individuals. Without irrigation these plants would not have developed an ear had July been dry, and no late tillering would have taken place. In a dry summer irrigation may thus increase the grain yield partly by increasing the number of grain producing plants.

Number of grains in ears

All the grain analyses have been done from the grains remaining on a $2 \mathrm{~mm}$ sieve after sieving, the grains smaller than $2 \mathrm{~mm}$ were thus screenings. The results of the analyses are presented in Table 7 and Figure 1.

The average number of grains per ear in the total research material was 6.2 without irrigation and 11.3 when irrigated. Irrigation in fact increased the number of grains per ear by as much as $83 \%$. On different farms the percentage numbers varied from 52 to 141 .

Irrigation increased the grain number per ear in all individual groups. The 
Table 7. Number of grains per ear.

\begin{tabular}{|c|c|c|c|c|c|c|c|c|c|}
\hline \multirow[t]{2}{*}{ Farm } & \multirow[t]{2}{*}{ Irrigation } & \multicolumn{7}{|c|}{ Grains per ear in individuals having } & \multirow{2}{*}{$\begin{array}{l}\text { Weighted } \\
\text { mean }\end{array}$} \\
\hline & & 1 ear & 2 ears & 3 ears & 4 ears & 5 ears & 6 ears & $>6$ ears & \\
\hline \multirow[t]{3}{*}{1} & Unirrigated & 8.7 & 5.3 & 5.5 & 4.1 & 3.8 & 3.6 & 6.8 & 5.05 \\
\hline & Irrigated & 12.8 & 13.3 & 13.4 & 12.1 & 13.0 & 3.0 & - & 12.16 \\
\hline & Effect & $+4.1 \star \star$ & $+8.0^{\star \star \star}$ & $+7.9^{\star \star \star}$ & $+8.0^{\star \star \star}$ & $+9.2^{\star \star \star}$ & -0.6 & - & $+7.11^{\star \star \star}$ \\
\hline \multirow[t]{3}{*}{2} & Unirrigated & 6.2 & 7.7 & 6.1 & 6.8 & 7.0 & 6.2 & 6.5 & 7.16 \\
\hline & Irrigated & 10.8 & 12.7 & 12.5 & 11.9 & 11.9 & 11.3 & 12.1 & 12.92 \\
\hline & Effect & $+4.6^{\star \star}$ & $+5.0^{\star}$ & $+6.4^{\star \star \star}$ & $+5.1 \star \star$ & $+4.9 * \star$ & $+5.1^{\star}$ & $+5.6^{\star \star}$ & $+5.76^{\star \star \star}$ \\
\hline \multirow[t]{3}{*}{3} & Unirrigated & 10.0 & 6.3 & 5.1 & 4.5 & 5.0 & 4.5 & - & 6.14 \\
\hline & Irrigated & 12.7 & 9.1 & 7.5 & 6.3 & 4.3 & 4.0 & - & 9.33 \\
\hline & Effect & $+2.7^{\star}$ & $+2.8 \star \star$ & $+2.4^{\star \star}$ & $+1.8^{\star}$ & -0.7 & -0.5 & - & $+3.19 * \star$ \\
\hline \multirow[t]{3}{*}{4} & Unirrigated & 8.5 & 6.3 & 6.6 & 6.8 & 6.9 & 6.7 & 6.8 & 6.43 \\
\hline & Irrigated & 11.7 & 9.5 & 11.2 & 11.5 & 10.4 & 9.9 & 11.1 & 10.92 \\
\hline & Effect & +3.2 & $+3.2^{\star}$ & $+4.6^{\star \star}$ & $+4.7^{\star \star}$ & $+3.5^{\star \star \star}$ & $+3.2^{\star}$ & $+4.3^{\star \star}$ & $+4.49^{\star \star \star}$ \\
\hline \multirow[t]{3}{*}{ Mean } & Unirrigated & 8.4 & 6.4 & 5.8 & 5.6 & 5.7 & 5.3 & - & 6.20 \\
\hline & Irrigated & 12.0 & 11.2 & 11.2 & 10.5 & 9.9 & 7.1 & - & 11.33 \\
\hline & Effect & $+3.6^{\star \star \star}$ & $+4.8^{\star \star \star}$ & $+5.4^{\star \star \star}$ & $+4.9^{\star \star \star}$ & $+4.2^{\star \star \star}$ & $+1.8 * \star$ & - & $+5.13^{\star \star \star}$ \\
\hline
\end{tabular}

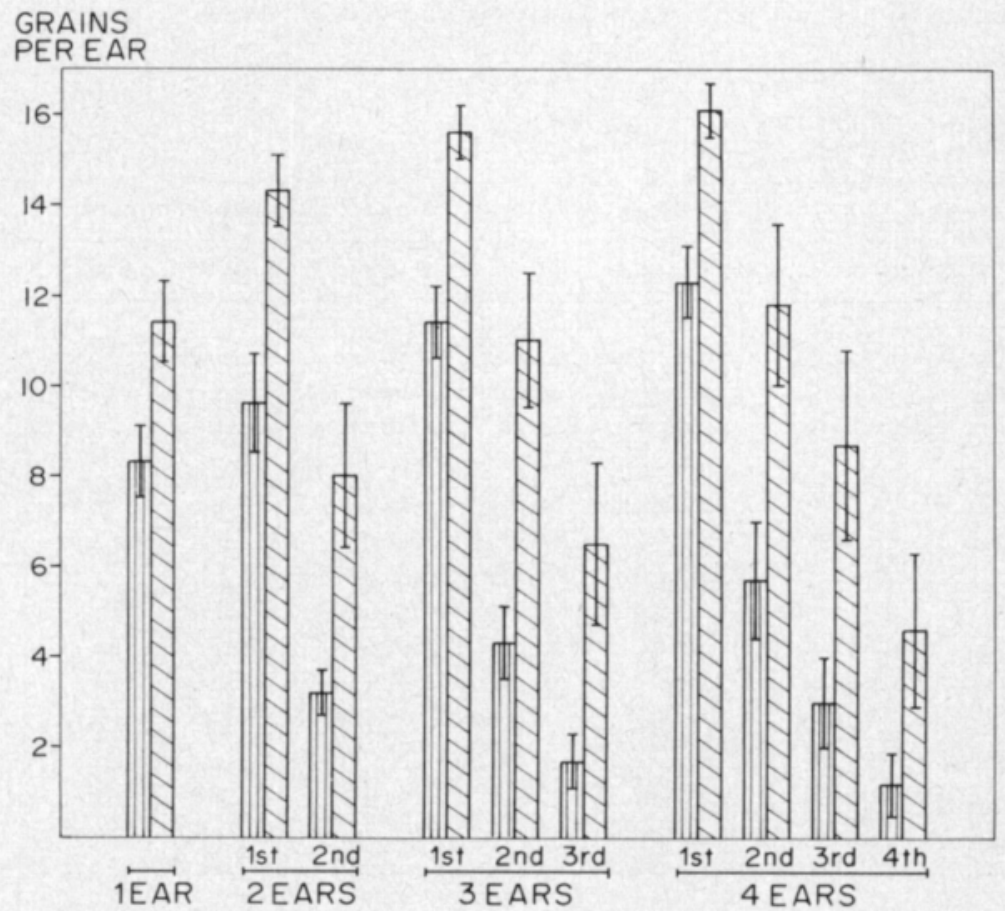

Fig. 1. Number of grains in ear in shoots of different stages without irrigation (colums with vertical lines) and when irrigated (columns with diagonal lines). The vertical lines indicate $95 \%$ significance ranges. 
increase was bigger among the secondary than among the primary shoots (Fig. 1). In other words: the ears of irrigated primary and secondary shoots were more equal in size than the ears of non-irrigated barley plants. This can also be seen in the following tabulation which gives the ratio of grains in first stage ears and secondary ears:

\begin{tabular}{|c|c|c|c|c|c|c|}
\hline & 2 ears & & & & 4 ear & \\
\hline & 1st & 1st & 1st & 1st & 1st & 1st \\
\hline & $\overline{2 \mathrm{nd}}$ & $\overline{2 n d}$ & $\overline{3 \mathrm{rd}}$ & $\overline{2 n d}$ & $\overline{3 \mathrm{rd}}$ & $\overline{4 \text { th }}$ \\
\hline Unirrigated & 3.0 & 2.7 & 6.7 & 2.2 & 4.1 & 10.3 \\
\hline Irrigated $\ldots .$. & 1.8 & 1.4 & 2.4 & 1.4 & 1.9 & 3.5 \\
\hline
\end{tabular}

The more ears there were in a plant the bigger was the first stage ear. This is only natural since abundant tillering indicates a strong plant with a first rate growth potential. Through irrigation the secondary shoots developed rather big ears, while without irrigation the ears of these shoots remained small. The small grain number of the secondary shoots of non-irrigated barley is also partly due to the green ears, in which a considerable number of the grains was smaller than $2 \mathrm{~mm}$.

Weight of grains

Irrigation increased the weight of grains on all of the four experimental farms (Table 8). The sheaf grain analyses showed an average increase effected

Table 8. Weight of grains, mg.

\begin{tabular}{|c|c|c|c|c|c|c|c|c|c|}
\hline \multirow[t]{2}{*}{ Farm } & \multirow[t]{2}{*}{ Irrigation } & \multicolumn{7}{|c|}{ Mean weight of grains in individuals having } & \multirow{2}{*}{$\begin{array}{c}\text { Weighted } \\
\text { mean }\end{array}$} \\
\hline & & 1 ear & 2 ears & 3 ears & 4 ears & 5 ears & 6 ears & $>6$ ears & \\
\hline \multirow[t]{3}{*}{1} & Unirrigated & 44.5 & 43.2 & 43.1 & 41.7 & 43.2 & 42.2 & 42.0 & 43.8 \\
\hline & Irrigated & 46.8 & 46.6 & 46.9 & 46.4 & 49.6 & 47.5 & - & 46.9 \\
\hline & Effect & +2.3 & $+3.4^{\star}$ & $+3.8^{\star}$ & $+4.7^{\star}$ & +6.4 & +5.3 & - & $+3.1^{*}$ \\
\hline \multirow[t]{3}{*}{2} & Unirrigated & 37.6 & 39.0 & 36.3 & 36.1 & 38.1 & 38.8 & 37.8 & 37.5 \\
\hline & Irrigated & 39.1 & 41.4 & 40.9 & 40.6 & 42.8 & 41.6 & 41.3 & 41.1 \\
\hline & Effect & +1.5 & +2.4 & $+4.6^{\star \star}$ & $+4.5^{\star}$ & +4.7 & +2.8 & $+3.5^{\star}$ & $+3.6^{\star}$ \\
\hline \multirow[t]{3}{*}{3} & Unirrigated & 45.6 & 44.6 & 43.0 & 43.8 & 42.9 & 41.8 & - & 44.5 \\
\hline & Irrigated & 50.7 & 48.5 & 50.0 & 49.5 & 49.0 & 49.8 & - & 50.1 \\
\hline & Effect & $+5.1^{\star}$ & $+3.9^{\star}$ & $+7.0^{\star \star \star}$ & $+5.7 * \star$ & $+6.1 * \star$ & +8.0 & - & $+5.6 \star \star$ \\
\hline \multirow[t]{3}{*}{4} & Unirrigated & 40.6 & 37.5 & 37.6 & 36.9 & 37.6 & 38.0 & 37.5 & 39.1 \\
\hline & Irrigated & 42.1 & 42.0 & 40.6 & 41.8 & 40.3 & 41.6 & 41.5 & 41.9 \\
\hline & Effect & +1.5 & $+4.5^{\star \star}$ & $+3.0^{*}$ & $+4.9 * \star$ & $+2.7^{\star}$ & $+3.6^{\star}$ & $+4.0^{\star \star}$ & +2.8 \\
\hline \multirow[t]{3}{*}{ Mean } & Unirrigated & 42.1 & 41.1 & 40.0 & 39.6 & 40.5 & 40.2 & - & 41.2 \\
\hline & Irrigated & 44.7 & 44.6 & 44.6 & 44.6 & 45.4 & 45.1 & - & 45.0 \\
\hline & Effect & $+2.6^{\star}$ & $+3.5^{\star \star \star}$ & $+4.6^{* \star \star}$ & $+5.0^{\star \star \star}$ & $+4.9^{\star \star \star}$ & $+4 \cdot 9^{\star}$ & - & $+3.8^{\star \star \star}$ \\
\hline
\end{tabular}




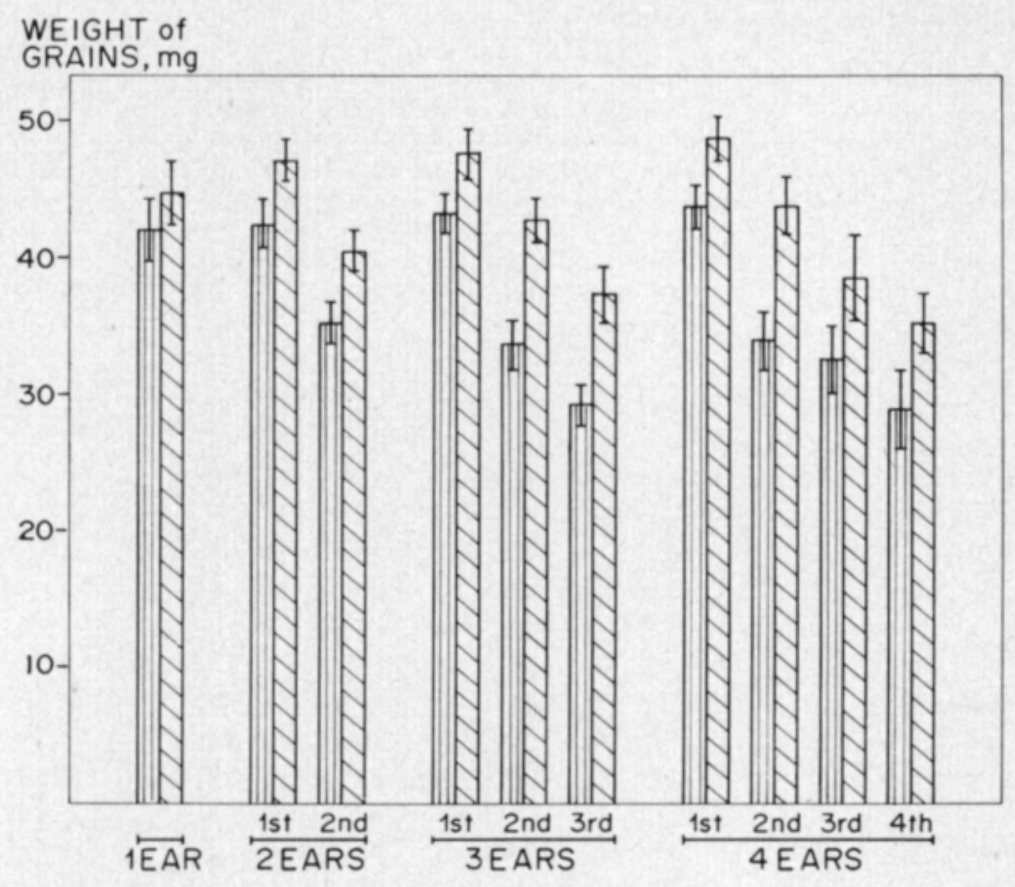

Fig. 2. Weight of grains in shoots of different stages without irrigation (columns with vertical lines) and when irrigated (columns with diagonal lines). The vertical lines indicate $95 \%$ significance ranges.

by irrigation from $41.2 \mathrm{mg}$ to $45.0 \mathrm{mg}$, i.e. about $9 \%$. According to Table 2 the corresponding increase of the grain weight analysed from the combineharvested yield was from $40.4 \mathrm{mg}$ to $44.8 \mathrm{mg}$ or $11 \%$.

Irrigation increased the grain weight to a greater extent among the plants with several ears than in plants with only one ear. As can be seen in Fig. 2, the effect of irrigation seems to have been most marked on the secondary ears of plants with many ears. In fact, irrigation affected the grain weight as well as the number of grains: it tended to equalize the grain yield difference between the primary and secondary ears.

\section{Grain yields}

The grain yields of sheaves are presented in Table 9. Irrigation increased the yield per square meter in the whole experiment from 261 grams to 444 grams (mean values) or $70 \%$. The corresponding yield increase in combineharvested plots was from 247 grams to 422 grams or $71 \%$. The mean values thus agree well with one another. On different farms the variations between the sheaf yields and combine-harvested yields were larger. On farms 1 and 2, the sheaf yields showed larger differences between non-irrigated and irrigated plots than did the combine yields, but on farms 3 and 4 the case is reversed. 
Table 9. Grain yield of sheaves, $\mathrm{g} / \mathrm{m}^{2}$.

\begin{tabular}{|c|c|c|c|c|c|c|c|c|c|}
\hline \multirow[t]{2}{*}{ Farm } & \multirow[t]{2}{*}{ Irrigation } & \multicolumn{7}{|c|}{ Grain yield of individual groups having } & \multirow[t]{2}{*}{ Total } \\
\hline & & 1 ear & 2 ears & 3 ears & 4 ears & 5 ears & 6 ears & $>6$ ears & \\
\hline \multirow[t]{3}{*}{1} & Unirrigated & 79 & 71 & 54 & 26 & 12 & 6 & 9 & 257 \\
\hline & Irrigated & 123 & 211 & 168 & 28 & 6 & 9 & - & 545 \\
\hline & Effect & $+44^{*}$ & $+140^{* * *}$ & $+114 *$ & +2 & -6 & +3 & -9 & $+288^{* * *}$ \\
\hline \multirow[t]{3}{*}{2} & Unirrigated & 29 & 38 & 44 & 49 & 38 & 27 & 54 & 279 \\
\hline & Irrigated & 61 & 81 & 113 & 84 & 48 & 33 & 37 & 457 \\
\hline & Effect & $+32 *$ & $+43^{*}$ & $+69^{* *}$ & $+35^{*}$ & +10 & +6 & -17 & $+178^{*}$ \\
\hline \multirow[t]{3}{*}{3} & Unirrigated & 65 & 100 & 66 & 20 & 4 & 3 & - & 258 \\
\hline & Irrigated & 143 & 152 & 76 & 25 & 4 & 5 & - & 405 \\
\hline & Effect & $+78^{* *}$ & $+52^{* *}$ & +10 & +5 & 0 & +2 & - & +147 *** \\
\hline \multirow[t]{3}{*}{4} & Unirrigated & 17 & 25 & 41 & 41 & 35 & 20 & 40 & 219 \\
\hline & Irrigated & 41 & 43 & 75 & 76 & 42 & 20 , & 15 & 312 \\
\hline & Effect & +24 & $+18^{*}$ & $+34^{*}$ & $+35^{*}$ & +7 & 0 & -25 & $+93^{*}$ \\
\hline \multirow[t]{3}{*}{ Mean } & Unirrigated & 48 & 58 & 51 & 34 & 22 & 14 & - & 261 \\
\hline & Irrigated & 92 & 121 & 108 & 53 & 25 & 17 & - & 444 \\
\hline & Effect & $+44^{* * *}$ & $+63^{* * *}$ & $+57^{* * *}$ & $+19^{* *}$ & +3 & +3 & - & $+183^{* * *}$ \\
\hline
\end{tabular}

The effect of irrigation on yield increase was biggest in plants with one, two or three ears. The yield per area of the individuals with more than 3 ears tended also to be bigger in the irrigated than in non-irrigated plots, despite the smaller number of these plants in the irrigated stands (Table 5).

The components of grain yield

Judging by the sheaf analyses irrigation affected the four components which form the barley yield as follows (Tables 3, 4, 7, and 8):

\begin{tabular}{|c|c|c|c|c|}
\hline & Unirrigated & Irrigated & Effect & Factor \\
\hline Plant individuals $/ \mathrm{m}^{2}$ & 398 & 394 & $-1 \%$ & 0.99 \\
\hline Ears/individual & 2.44 & 2.11 & $-14 \%$ & 0.86 \\
\hline Grains/ear & 6.20 & 11.33 & $+83 \%$ & 1.83 \\
\hline Weight of grain, $\mathrm{mg}$ & 41.2 & 45.0 & $+9 \%$ & 1.09 \\
\hline
\end{tabular}

Total effect $(0.99 \times 0.86 \times 1.83 \times 1.09=1.70)=+70 \%$

These figures are probably characteristic of the average effects of irrigation on the experimental farms. The volume of the total effect varied on different farms, but the division into the four above categories was approximately the same on all farms. 


\section{Discussion}

In examining the results of the present study it should be kept in mind that during the growing season in question a very dry June was followed by a rainy July. Had July been less rainy, late tillering would not have occurred, and different results would have been obtained. In the following the effects of irrigation in these two cases will be examined. In addition to the present study the discussion is based on the study of ELONEN and KARA (1972), in which irrigation results affecting the grain quality on the same farm in different years proved very varied. The earlier investigations of Elonen et al. (1967 a, b), which show that irrigation in June promotes grain ripening, while in July it causes late tillering and retards ripening, likewise agree with the following conclusions:

I. Providing a dry June is followed by a dry or nor$\mathrm{m}$ a $1 \mathrm{Jul} \mathrm{y}$, irrigation performed in June has the following effect on spring cereals on clay fields in South Finland:

1. Irrigation increases the vegetative growth markedly already in June. This applies to the development of roots as well as the upper parts of plant (KÄHÄRI and ELONEN 1969). At the same time it greatly improves the uptake of nutrients (KAILA and ELONEN 1970 a). The vigorous growth in June produces strong tillering among plant species or varieties with a tendency to tiller (TUOMIKoski and Elonen, unpubl. data). Irrigated grain continues its vigorous growth in July forming a number of big ears which ripen evenly in August.

2. Without irrigation growth is weaker as from the middle of June and continues to be weaker in July and even in August (KAILA and EloNEN 1970 b). In an exceptionally dry summer non-irrigated stands may be forced into ripening earlier than normally, and irrigation may seem to retard the ripening (Pohjanhermo and Heinonen 1960). The non-irrigated yield remains smaller than the irrigated yield owing mainly to the weaker tillering of the plants and the smaller grain number per ear. In addition the weakest plant individuals may decline in growth to such an extent that they develop no ear or that the ears are empty of grains. Unless the dry season in July is exceptionally dry, the mean grain weight may approximate the weight of the grains irrigated (ELONEN et al. $1967 \mathrm{~b}$, ELONEN and KARA 1972).

II. If a dry June is followed by a rainy July the following development is likely to take place:

1. Irrigation performed in June has the same effects as above. The vigorous stand continues its steady growth despite the rains in July. No detrimental late tillering occurs because the tillering and the uptake of usable growing space has already taken place in June. Moreover, the resources of soil nitrogen are by the beginning of July significantly smaller (KAILA and Elonen 1971).

2. In the non-irrigated, sparse and low stands there is plenty of space 
for growing, and the soil still contains abundant quantities of unused fertilizer nitrogen. When the July rains suddenly improve the state of soil water and nutrients, and there is still growing space in abundance, the individual plants begin to develop new shoots despite the fact that the shoots developed in June already have ears. These late shoots do not usually have sufficient time to ripen and can not significantly influence the amount of the yield. Late tillering affects adversely the harvesting, drying and winnowing, however, and weakens the quality of the yield as may be seen from the results of the present study.

In comparing corresponding irrigation researches in other countries with Finnish investigations, the following brief summing up can be made: Irrigation and advantageous soil moisture conditions increase tillering (CAMPBELL et al. 1969, DAy and Intalap 1970), the number of grains (van der PaAuw 1949, Denmead and Shaw 1960, Chinoy 1962) and the weight of the grains (Aspinall et al. 1964, Langer 1967, Day and Intalapp 1970). The increases in grain yields in Finland are based on the same components, their significance, however, varies in different years.

A c know ledgements. Mrs Marita Hagman did all the sheaf analyses included in this study. The reliability of the results is due expressly to her skilful work.

\section{REFERENCES}

Aspinall, D., Nicholls, P. B. \& May, L. H. 1964. The effects of soil moisture stress on the growth of barley. Austr. J. Agric. Res. 15: 729-745.

Campbell, C. A., Pelton, W. L. \& Nielsen, K. F. 1969. Influence of solar radiation and soil moisture on growth and yield of Chinook-wheat. Can. J. Pl. Sci. 49: 685-699.

Chrnoy, J. J. 1962. Physiology of drought resistance in wheat. IV Effect of wilting at different growth and developmental stages on plant characters determining yield of grain in eight varieties of wheat. Phyton 19:5-10.

DAY, A. D. \& Intalap, S. 1970. Some effects of soil moisture stress on the growth of wheat (Triticum aestivum L. emthel). Agron. J. 62: 27-29.

Denmead, O. T. \& Shaw, R. H. 1960. The effects of soil moisture stress at diffenret stages of growth on the development and yield of corn. Agron. J. 52: 272-274.

Elonen, P. \& KarA, O. 1972. Sprinkler irrigation of clay soils in southern Finland. IV. The effect of repeated applications of water and nitrogen fertilization on spring cereals. J. Scient. Agric. Soc. Finl. 44: 149-163.

- - , Nieminen, L. \& KarA, O. 1967 a. Sprinkler irrigation on clay soils in southern Finland. II. Effect on the grain yield of spring cereals. J. Scient. Agric. Soc. Finl. 39: $78-89$.

- - , Nieminen, L. \& KARA, O. 1967 b. Sprinkler irrigation on clay soils in southern Finland. III. Effect on the quality of grain yield. J. Scient. Agric. Soc. Finl. 39: 90-98.

KAILA, A. \& Elonen, P. 1970 a. Influence of irrigation and placement of nitrogen fertilizers on the uptake of nitrogen by spring wheat. J. Scient. Agric. Soc. Finl. 42: 123-130.

- - \& ELONEN, P. 1970 b. Influence of irrigation and supply of available nitrogen on growth and nutrient content of spring wheat. J. Scient. Agric. Soc. Finl. 42: 205-215.

- - \& Elonen 1971. Effect of irrigation on fertilizer nitrogen in arable clay soil. Acta Agr. Fenn. 123: 126-135. 
KÄHÄRI, J. \& ELONEN, P. 1969. Effect of placement of fertilizer and sprinkler irrigation on the development of spring cereals on the basis of root investigations. J. Scient. Agric. Soc. Finl. 41: 89-104.

LANGer, R. H. M. 1967. Physiological approaches to yield determination in wheat and barley. Field Crop Abstr. 20: 101-106.

PAAUw, F, van der 1949. Water relations of oats with special attention to the influence of periods of drought. Plant and Soil 1: 303-341.

Pohjanhermo, O. \& Heinonen, R. 1960. The effect of irrigation on root development, water use, nitrogen uptake and yield characteristics of several barley varieties. Acta Agr. Fenn. 95, 6: 1-18.

\title{
Selostus
}

\section{Sadetus ohran haitallisen myöhäisversonnan estäjänä}

\author{
Simo Kivisaari ja PaAvo Elonen ${ }^{1}$ ) \\ Yliopiston maanviljelyskemian laitos, 00710 Helsinki 71
}

Tutkimus perustuu Yliopiston maanviljelyskemian laitoksen ja Maatalouskoneiden tutkimuslaitoksen kesällä 1970 suorittamiin yhteisiin sadetuskokeisiin. Tällöin kuivaa kesäkuuta seurannut sateinen heinäkuu aiheutti kevätviljoihin runsaasti haitallista myöhäisversontaa laajoilla alueilla Etelä-Suomessa, paikoin myős Keski- ja Pohjois-Suomessa.

Neljässä sadetuskenttäkokeessa, jotka sijaitsivat Etelä-Suomen savialueella, kesäkuun puolivälissä suoritettu sadetus $(2 \times 30 \mathrm{~mm})$ lisäsi 2-tahoisen ohran jyväsatoa keskimäärin 1750 $\mathrm{kg} /$ ha eli $71 \%$ (vaihtelualue $49-104 \%$ ). Lisäksi sadetus paransi huomattavasti ohran laatua estämällä haitallisen myöhäisversonnan. Tasaisesti tuleentunut sadetettu ohra oli puitaessa keskimäärin $12.3 \%$-yksikköä kuivempaa ja sen hehtolitran paino oli 3.6 kg korkeampi verrattuna sadettamattomaan, vihreitä jyviä sisältäneeseen ohraan.

Koekentiltä sadonkorjuun yhteydessä kerättyjen viljalyhteiden analysointi osoitti, että sadettamattomaan verrattuna sadetettu ohra sisälsi: a) yhtä paljon yksilöitä $/ \mathrm{m}^{2}$, b) $14 \%$ vähemmän tähkiä/yksilö, c) $83 \%$ enemmän jyviä/tähkä, d) $9 \%$ painavampia jyviä, e) eli yhteisvaikutuksena $70 \%$ korkeamman jyväsadon.

Tulosten tarkastelussa pohditaan myöhäisversonnan syitä sekä sadetuksen merkitystä tämän haitallisen ilmiōn estäjänä. Samalla todetaan, että sellaisina vuosina, jolloin myöhäisversontaa ei muodostu, sadetus vaikuttaa jyväsadon komponentteihin eri tavoin kuin tässä tutkimuksessa.

1) Nykyinen osoite: Maatalouden tutkimuskeskus, maantutkimuslaitos, 01300 Vantaa 30 